\title{
Pengaruh Masukan Kendali Terhadap Hasil Identifikasi Parameter Pesawat Udara Konfigurasi Konvensional Matra Terbang Longitudinal
}

\author{
Effect of Control Input on the Results of Parameter Identification of Aircraft \\ Conventional Configuration of Longitudinal Flying Dimension
}

\author{
Eries Bagita Jayanti $\left.{ }^{*}, 1\right)$, Novita Atmasari ${ }^{1)}$, Hidayati Mardikasari ${ }^{1)}$, Ardian Rizaldi ${ }^{1)}$, Fuad Surastyo Pranoto ${ }^{1)}$, \\ Singgih Satrio Wibowo ${ }^{2)}$ \\ ${ }^{1)}$ Pusat Teknologi Penerbangan, Lembaga Penerbangan dan Antariksa Nasional \\ Jl. Lkr. Selatan, Sukamulya, Rumpin, Bogor, Jawa Barat, Indonesia 16350 \\ ${ }^{2)}$ Program Studi Teknik Aeronautika, Jurusan Teknik Mesin, Politeknik Negeri Bandung \\ Jl. Gegerkalong Hilir, Ciwaruga, Parongpong, Bandung Barat, Jawa Barat, Indonesia 40559
}

\begin{abstract}
Cara sitasi: E. B. Jayanti, N. Atmasari, H. Mardikasari, A. Rizaldi, F. S. Pranoto, and S. S. Wibowo, "Pengaruh Masukan Kendali Terhadap Hasil Identifikasi Parameter Pesawat Udara Konfigurasi Konvensional Matra Terbang Longitudinal," Jurnal Teknologi dan Sistem Komputer, vol. 7, no. 1, 2019. doi: 10.14710/jtsiskom.7.1.2019.25-30, [Online].
\end{abstract}

\begin{abstract}
Parameter identification is a process to get real characteristics of the motion dynamics of an object which can then be used to build the dynamics model of the object, which has a very high level of validity and accuracy. The modeling process is usually carried out using aircraft input data and the results of existing navigation data recording. From the data, the model parameters are estimated using the simple least square method. In this study, the simulation was carried out by varying the deflection input in the control field and simulation time. The input given to the longitudinal dimension is the deflection of the elevator control field. The results of parameter identification in the Corsair A-7A plane in the longitudinal dimension indicate that the input form 32-1 has a smaller error value than using doublet and pulse inputs. This shows that the input form 3-2-1 is most suitable for the longitudinal dimension among the given inputs.
\end{abstract}

Keywords - aircraft modelling; parameter identification; input variations; longitudinal dimension

\begin{abstract}
Abstrak - Identifikasi parameter merupakan suatu cara untuk mendapatkan sifat-sifat nyata dinamika gerak suatu benda yang kemudian dapat digunakan untuk membangun model dinamika benda tersebut, yang memiliki tingkat kesahihan dan ketelitian sangat tinggi. Proses pemodelan dilakukan dengan menggunakan data input pesawat dan hasil perekaman data navigasi yang sudah ada. Dari data yang diperoleh, parameter model diestimasi dengan menggunakan metode ordinary least square. Pada penelitian ini simulasi dilakukan dengan memvariasikan input defleksi bidang kendali dan
\end{abstract}

\footnotetext{
*) Penulis korespondensi (Eries Bagita Jayanti)

Email: eries.bagita@lapan.go.id
}

waktu simulasi. Input yang diberikan pada matra longitudinal adalah defleksi bidang kendali elevator. Hasil identifikasi parameter pada pesawat Corsair A7A matra longitudinal menunjukkan bahwa bentuk inputan 3-2-1 memiliki nilai galat yang lebih kecil dibandingkan menggunakan input doublet dan pulse. Hal ini menunjukkan bahwa bentuk input 3-2-1 paling sesuai untuk matra longitudinal diantara input-input yang telah diberikan.

Kata Kunci - pemodelan pesawat udara; identifikasi parameter; variasi input; matra longitudinal

\section{Pendahuluan}

Identifikasi parameter (IP) adalah sebuah proses memperkirakan karakteristik dinamis suatu sistem, berupa parameter-parameter sifat dinamis, menggunakan data riwayat input dan output yang diketahui [1]-[3]. Input data berasal dari defleksi bidang kendali dan output data adalah gerakan pesawat yang direpresentasikan dalam matriks-matriks persamaan gerak. Model matematika yang terbentuk digunakan untuk mensimulasikan gerak terbang. Dengan dilakukannya simulasi, dapat diketahui bagaimana respons gerak pesawat ketika diberikan perlakuan pada bidang kendali. Pada umumnya, input yang diberikan untuk simulasi adalah bentuk input pulse, doublet dan 32-1-1. Akan tetapi, untuk matra longitudinal, belum dapat diketahui, bentuk input yang seperti apakah yang paling sesuai, dalam artian yang dapat mengeksitasi modus gerak yang khas (phugoid dan short period) pada matra longitudinal.

Penelitian IP terhadap UAV telah dilakukan oleh tim LAPAN bekerjasama dengan tim POLBAN sejak 2012 [4]. Pada penelitian tersebut teknik IP dilakukan dengan memanfaatkan uji virtual menggunakan software simulasi terbang khusus, dengan metode least square. 

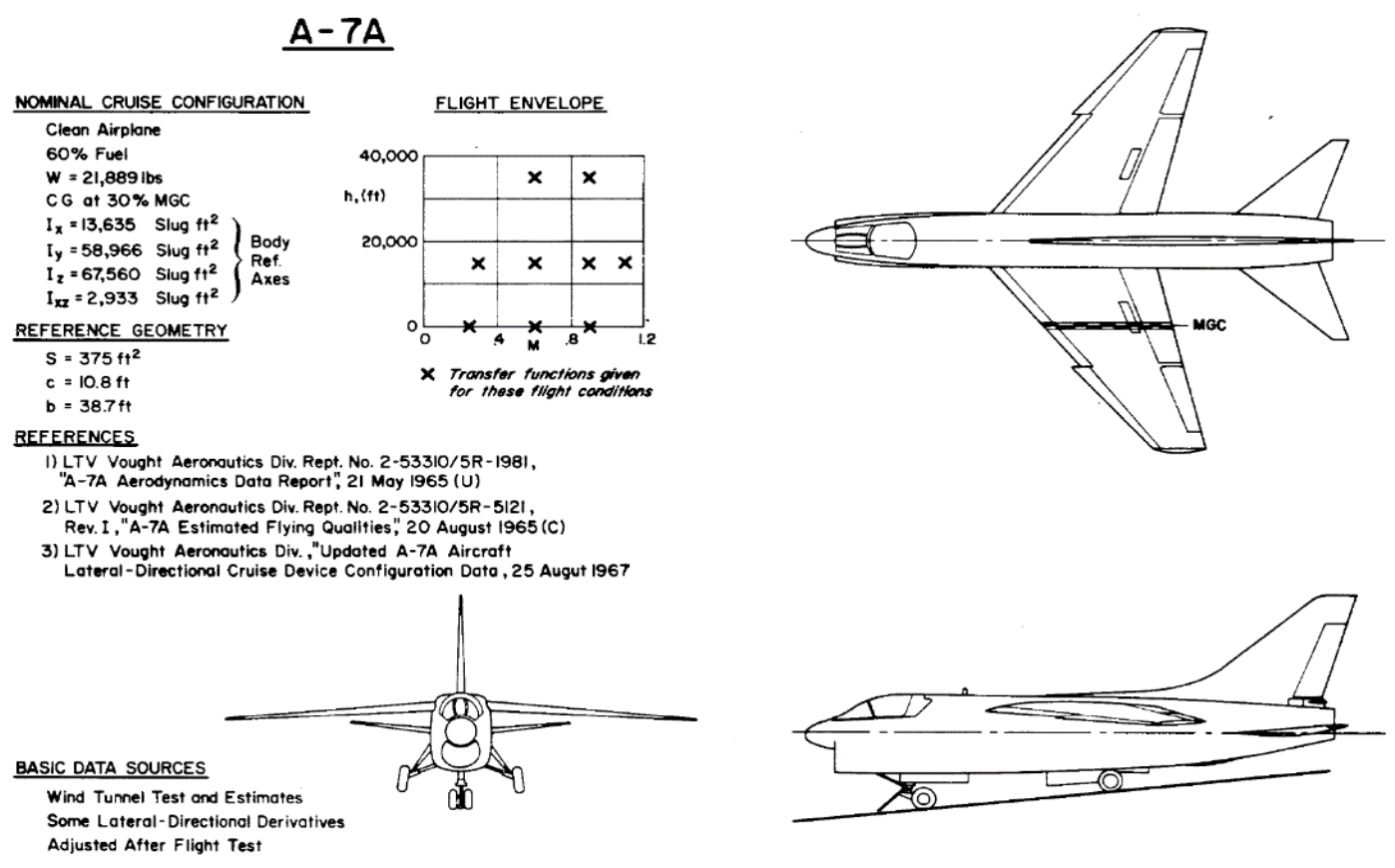

Gambar 1. Pesawat jet A-7A [5]

Kajian dikhususkan pada mode terbang longitudinal. Pada penelitian tersebut berbagai kajian khusus dilakukan, diantaranya adalah pembuatan algoritma IP untuk mode terbang longitudinal, lateral, dan pengaruh bentuk input (step, doublet, 3-2-1, dan variasinya terhadap waktu) terhadap hasil identifikasi.

Bentuk doublet pada umumnya digunakan untuk identifikasi parameter seperti dalam [5] dan identifikasi sistem pesawat udara tanpa awak sayap dalam [6]. Doublet sendiri merupakan bentuk variasi input dengan diberikan sinyal PWM (pulse width modulation) tinggi selama waktu $t$ dan langsung diberikan sinyal PWM rendah selama waktu t. Saraswathi [5] menggunakan tiga pilihan input yaitu step, doublet dan 3-2-1-1. Respons input step tidak digunakan untuk estimasi turunan kestabilan dan kendali. Oleh karena itu, jika estimasi turunan untuk input yang standart yaitu seperti doublet dan 3-2-1-1, input step dapat menggunakan cross-validated. Majid dkk. [6] menjelaskan tentang identifikasi sistem yang dilakukan berdasar pada data eksperimen pesawat udara tanpa awak jenis Bixler menggunakan struktur model Autoregressive with exogeneous input (ARX) dan telah berhasil merepesentasikan pesawat tanpa awak tetap jenis Bixler dengan struktur model tersebut.

Bentuk input pulse tidak sering digunakan. Respons frekuensinya diperoleh dengan transformasi fourier dari output dan input pada titik-titik diskrit. Input ini terbatas pada sistem linear sederhana yang rendah [7]. Doublet, step, dan input pulse durasi terbatas pada umumnya digunakan untuk identifikasi parameter pesawat pada linear dan non-linear model. Namun parameter tersebut mungkin sangat buruk dan mungkin tidak dapat diidentifikasi. Uji terbang dengan waktu yang lebih panjang diperlukan untuk mendapatkan estimasi yang baik pada semua parameter.

Input yang optimal dipertimbangkan dari identifikasi pada setiap kestabilan dan kendali turunan langsung.
Input tersebut dapat diatur untuk mendapatkan identifikasi yang baik pada semua parameter atau untuk mengidentifikasi parameter yang menjadi fokus penelitian saja [7]. Selanjutnya, pada perkembangan terkait penelitian pada desain input yang optimal, input 3-2-1-1 tetap sampai saat ini sebagai yang paling diterima di seluruh dunia dan dimanfaatkan oleh komunitas uji penerbangan internasional [8].

Penelitian ini melakukan simulasi dengan memvariasikan input defleksi bidang kendali dan waktu simulasi. Input yang divariasikan adalah pulse, doublet dan bentuk input 3-2-1. Tujuannya adalah mengidentifikasi input untuk IP yang paling sesuai bagi matra longitudinal dan mengamati pengaruh waktu simulasi. Proses pemodelan dilakukan dengan menggunakan data input pesawat dan hasil perekaman data uji terbang yang sudah ada. Dari data yang diperoleh, parameter model diestimasi dengan menggunakan metode ordinary least square. Penelitian ini menggunakan pesawat udara A-7A pada matra longitudinal dengan input bidang defleksi pada elevator.

\section{METODE PENELITIAN}

Tahapan penelitian yang dilakukan adalah melakukan simulasi linier, merekam perilaku pesawat, dan identifikasi hasil matriks terhadap acuan.

\section{A. Pesawat Udara A-7A}

Pesawat yang dipilih adalah Corsair A-7A LingTempco-Vought (LTV), yaitu sebuah pesawat carrier berbasis pertama yang terbang di pertengahan tahun 1960-an (Gambar 1). Pesawat ini bermesin tunggal dengan pilot tunggal. Airframe stabil pada semua kondisi terbang, meskipun derajat kestabilannya masih rendah. Pesawat dilengkapi dengan sistem pembesaran stabilitas tiga sumbu sederhana. Pesawat ini memiliki 
kecepatan hingga sekitar 1.2 mach [9], [10]. Data aerodinamika pesawat tersebut dinyatakan pada Tabel 1 .

\section{B. Identifikasi Parameter (IP)}

Identifikasi parameter memperkirakan karakteristik dinamis dari suatu sistem menggunakan data riwayat input dan output yang diketahui. IP bertujuan untuk mendapatkan nilai-nilai dari semua parameter yang ada dalam model pesawat dalam penelitian tersebut. Dengan demikian untuk mendapatkan angka-angka dari parameter gerak pesawat udara (seperti turunan kestabilan dan kendali frekuensi dan damping gerak phugoid), maka metode yang dipakai adalah teknik parametrik. Metode yang digunakan dalam penelitian ini adalah equation error yang paling praktis. Persamaan state space untuk dinamika gerak ditunjukkan dalam Persamaan 1. Gerak ini direkam dalam suatu himpunan selang waktu diskrit t sehingga dapat dituliskan dalam bentuk seperti Persamaan 2. Parameter $\underline{\theta}$ merupakan vektor dari parameter yang dicari (yang belum diketahui). Estimasi vektor parameter dihitung menggunakan kriteria galat OLS (Ordinary Least Square) dengan Persamaan 3.

$$
\begin{gathered}
\underline{x}=A \underline{x}+B \underline{u} \\
\underline{z}=H \underline{\theta}+\underline{v} \\
\theta=\left[H^{\prime} H\right]^{-1}+H^{\prime} z
\end{gathered}
$$

\section{Identifikasi Gerak Longitudinal}

Identifikasi parameter pada gerak longitudinal bertujuan untuk mendapatkan nilai-nilai state space berikut, dengan input tunggal (single input) yaitu defleksi elevator. Data uji terbang yang akan digunakan sebagai bahan pengujian mekanisme IP (identifikasi parameter) adalah uji terbang virtual untuk pesawat A7A pada ketinggian $4572 \mathrm{~m}$ dan kecepatan $102 \mathrm{~m} / \mathrm{s}$, yang dilakukan dengan melakukan simulasi terhadap persamaan linearnya yang telah diketahui. Semua parameter yang digunakan dalam simulasi dijabarkan pada Tabel 2.

Simulasi terhadap persamaan liniernya ditunjukkan dalam Persamaan 4. Jumlah variabel keadaan $m$ adalah 4 (yaitu $u, w, q$ dan $\theta$ ) dan jumlah input adalah 1 yaitu $\delta_{e}$. Dengan substitusi nilai-nilai parameter ke dalam Persamaan 4, diperoleh Persamaan 5. Jika gerak pesawat yang dinyatakan dalam state-space di atas direkam dalam suatu himpunan selang waktu diskrit $t=t(0), t(1), \cdots, t(n)$ dan jika Persamaan 1 berlaku maka pada setiap titik waktu Persamaan 5 juga berlaku. Parameter $u(0), \alpha(0), q(0), \operatorname{dan} \theta(0) \quad$ masing-masing adalah variabel keadaan yang diukur pada saat $t=t(0)$, sedangkan $\delta_{e}(0)$ adalah defleksi elevator diukur pada saat $t=t(0)$, dan $\varepsilon(0)$ adalah galat pengukuran pada saat $t=t(0)$.
Tabel 1. Data aerodinamik pesawat A-7A untuk setiap kasus penerbangan [10]

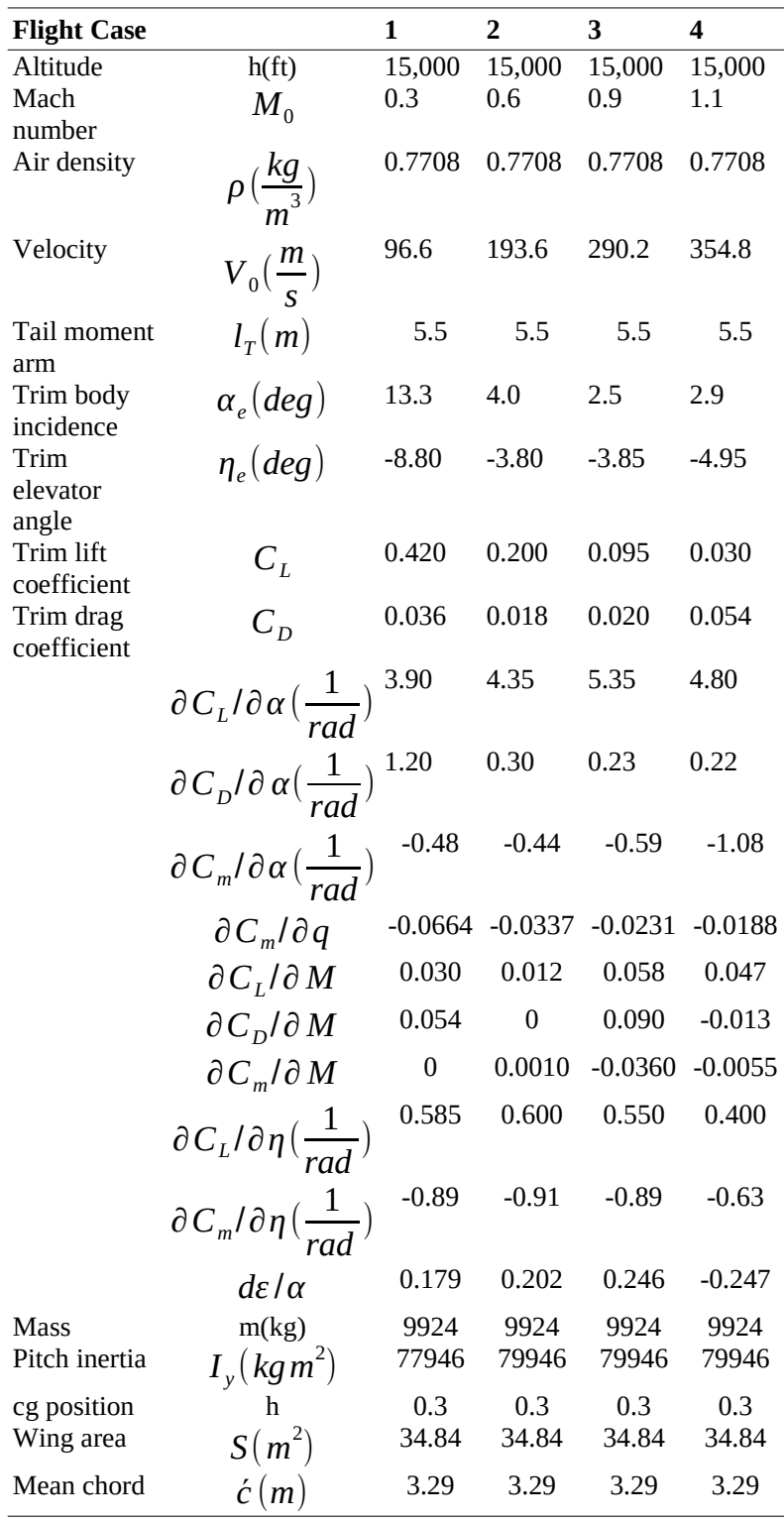

$$
\begin{aligned}
& \left\{\begin{array}{c}
\dot{u} \\
\dot{w} \\
\dot{q} \\
\dot{\theta}
\end{array}\right\}=\left[\begin{array}{cccc}
x_{u} & x_{w} & x_{q} & x_{\theta} \\
z_{u} & z_{w} & z_{q} & z_{\theta} \\
m_{u} & m_{w} & m_{q} & m_{\theta} \\
0 & 0 & 1 & 0
\end{array}\right]\left\{\begin{array}{c}
u \\
w \\
q \\
\theta
\end{array}\right\}+\left\{\begin{array}{c}
x_{\delta_{e}} \\
z_{\delta_{e}} \\
m_{\delta_{e}} \\
0
\end{array}\right\} \delta_{e}
\end{aligned}
$$

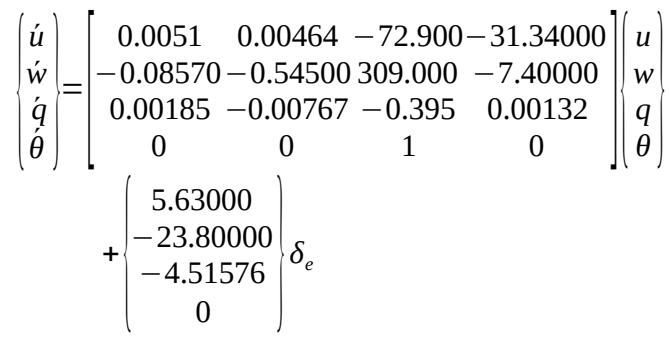

Persamaan 6 dapat diturunkan menjadi Persamaan 7. $s(n)=\left\{\begin{array}{lllll}u(n) & \alpha(n) & q(n) & \theta(n) & \delta_{e}(n)\end{array}\right\}$ adalah matrik baris berukuran $1 \times l$ dengan $l=m+u=4+1=5$, sedangkan 
Tabel 2. Parameter hasil uji terbang pesawat A-7A

\begin{tabular}{|c|c|c|c|c|}
\hline Parameter & Matlab & Nilai & Satuan & Deskripsi \\
\hline$x_{u}$ & $\mathrm{Xu}$ & 0.0050 & $\mathrm{~m} / \mathrm{s}$ & $\begin{array}{l}\text { Kecepatan maju ke depan } \\
\text { pada sumbu longitudinal }\end{array}$ \\
\hline$x_{w}$ & $X_{w}$ & 0.0046 & $\mathrm{~m} / \mathrm{s}$ & $\begin{array}{l}\text { Kecepatan vertikal pada } \\
\text { sumbu longitudinal }\end{array}$ \\
\hline$x_{q}$ & $\mathrm{Xq}$ & -72.9000 & $\mathrm{~m} / \mathrm{s}$ & $\begin{array}{l}\text { Kecepatan sudut pitch } \\
\text { pada sumbu longitudinal }\end{array}$ \\
\hline$x_{\theta}$ & $x t$ & -31.3400 & derajat & $\begin{array}{l}\text { Sudut pitch pada sumbu } \\
\text { longitudinal }\end{array}$ \\
\hline$x_{\delta_{e}}$ & Xde & 5.6300 & derajat & $\begin{array}{l}\text { Defleksi elevator pada } \\
\text { sumbu longitudinal }\end{array}$ \\
\hline$Z_{u}$ & $\mathrm{Zu}$ & -0.0857 & $\mathrm{~m} / \mathrm{s}$ & $\begin{array}{l}\text { Kecepatan maju ke depan } \\
\text { pada sumbu vertikal }\end{array}$ \\
\hline$Z_{w}$ & Zw & -0.5450 & $\mathrm{~m} / \mathrm{s}$ & $\begin{array}{l}\text { Kecepatan vertikal pada } \\
\text { sumbu vertikal }\end{array}$ \\
\hline$Z_{q}$ & $\mathrm{Zq}$ & 309.0000 & $\mathrm{~m} / \mathrm{s}$ & $\begin{array}{l}\text { Kecepatan sudut pitch } \\
\text { pada sumbu vertikal }\end{array}$ \\
\hline$z_{\theta}$ & Zt & -7.4000 & derajat & $\begin{array}{l}\text { Sudut pitch pada sumbu } \\
\text { vertikal }\end{array}$ \\
\hline$z_{\delta_{e}}$ & Zde & -23.8000 & derajat & $\begin{array}{l}\text { Defleksi elevator pada } \\
\text { sumbu vertikal }\end{array}$ \\
\hline$m_{u}$ & $\mathrm{Mu}$ & 0.0018 & $\mathrm{~kg} \cdot \mathrm{m}^{2}$ & $\begin{array}{l}\text { Momen aerodinamika } \\
\text { kecepatan maju ke depan } \\
\text { pada sumbu lateral }\end{array}$ \\
\hline$m_{w}$ & Mw & -0.0076 & kg.m² & $\begin{array}{l}\text { Momen aerodinamika } \\
\text { kecepatan vertikal pada } \\
\text { sumbu lateral }\end{array}$ \\
\hline$m_{q}$ & $\mathrm{Mq}$ & -0.3950 & $\mathrm{~kg} \cdot \mathrm{m}^{2}$ & $\begin{array}{l}\text { Momen aerodinamika } \\
\text { kecepatan sudut pitch } \\
\text { pada sumbu lateral }\end{array}$ \\
\hline$m_{\theta}$ & Mt & 0.0013 & $\mathrm{~kg} \cdot \mathrm{m}^{2}$ & $\begin{array}{l}\text { Momen aerodinamika } \\
\text { sudut pitch pada sumbu } \\
\text { lateral }\end{array}$ \\
\hline$m_{\delta_{e}}$ & Mde & -4.5157 & $\mathrm{~kg} \cdot \mathrm{m}^{2}$ & $\begin{array}{l}\text { Momen aerodinamika } \\
\text { defleksi elevator pada } \\
\text { sumbu lateral }\end{array}$ \\
\hline
\end{tabular}

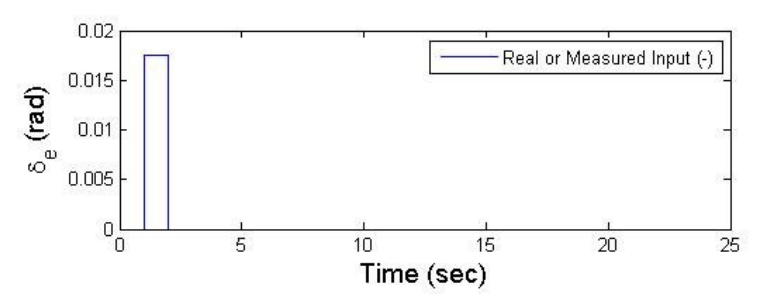

Gambar 2. Bentuk masukan pulse

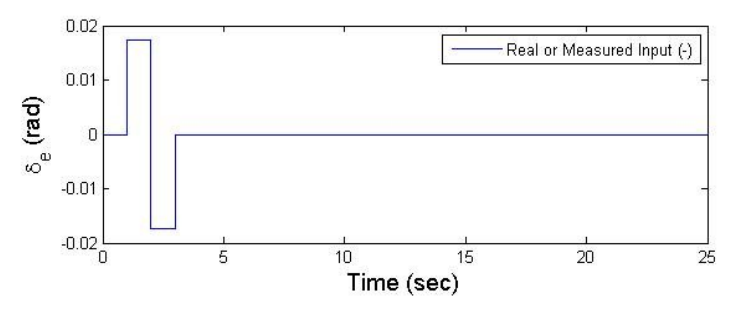

Gambar 3. Bentuk masukan doublet

$0_{1 \times 5}=\left[\begin{array}{lllll}0 & 0 & 0 & 0 & 0\end{array}\right]$. Persamaan ini dapat ditulis ulang dalam bentuk umum menjadi Persamaan 8. Parameter $\underline{Z}$ adalah matrik atau vektor nilai parameter keadaan yang telah direkam pada selang waktu diskrit. $H$ adalah matrik keadaan yang memiliki dimensi $n \times(m l)=n \times(4 \cdot 5)=n \times 20$. $\underline{\theta}$ adalah vektor parameter

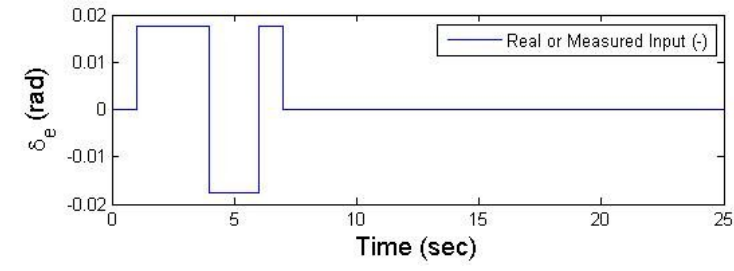

Gambar 4. Bentuk masukan 3-2-1

yang dicari, Vektor parameter $\underline{\theta}$ (yang belum diketahui) dihitung menggunakan kriteria galat OLS (Ordinary Least Square) seperti Persamaan 3.

$$
\begin{aligned}
& u(0)=x_{u} u(0)+x_{\alpha} \alpha(0)+x_{q} q(0)+x_{\theta} \theta(0)+x_{\delta_{e}} \delta_{e}(0)+\varepsilon(0) \\
& \dot{\alpha}(0)=z_{u} u(0) \quad+z_{\alpha} \alpha(0) \quad+z_{q} q(0) \quad+z_{\theta} \theta(0) \quad+z_{\delta_{e}} \delta_{e}(0) \quad+\varepsilon(0) \\
& \dot{q}(0)=m_{u} u(0)+m_{\alpha} \alpha(0)+m_{q} q(0)+m_{\theta} \theta(0)+m_{\delta_{e}} \delta_{e}(0)+\varepsilon(0) \\
& \dot{\theta}(0)=0 \quad+0 \quad+q(0) \quad+0 \quad+0 \quad+\varepsilon(0) \\
& \dot{u}(1)=x_{u} u(1) \quad+x_{\alpha} \alpha(1) \quad+x_{q} q(1)+x_{\theta} \theta(1)+x_{\delta_{e}} \delta_{e}(1)+\varepsilon(1) \\
& \dot{\alpha}(1)=z_{u} u(1) \quad+z_{\alpha} \alpha(1) \quad+z_{q} q(1) \quad+z_{\theta} \theta(1) \quad+z_{\delta_{e}} \delta_{e}(1)+\varepsilon(1) \\
& \dot{q}(1)=m_{u} u(1)+m_{\alpha} \alpha(1)+m_{q} q(1)+m_{\theta} \theta(1)+m_{\delta_{e}} \delta_{e}(1)+\varepsilon(1) \text { (6) } \\
& \dot{\theta}(1)=0 \quad+0 \quad+q(1) \quad+0 \quad+0 \quad+\varepsilon(1) \\
& \dot{u}(n)=x_{u} u(n)+x_{\alpha} \alpha(n)+x_{q} q(n)+x_{\theta} \theta(n)+x_{\delta_{e}} \delta_{e}(n)+\varepsilon(n) \\
& \dot{\alpha}(n)=z_{u} u(n) \quad+z_{\alpha} \alpha(n)+z_{q} q(n) \quad+z_{\theta} \theta(n)+z_{\delta_{e}} \delta_{e}(n)+\varepsilon(n) \\
& \dot{q}(n)=m_{u} u(n)+m_{\alpha} \alpha(n)+m_{q} q(n)+m_{\theta} \theta(n)+m_{\delta_{e}} \delta_{e}(n)+\varepsilon(n) \\
& \dot{\theta}(n)=0 \quad+0 \quad+q(n) \quad+0 \quad+0 \quad+\varepsilon(n)
\end{aligned}
$$

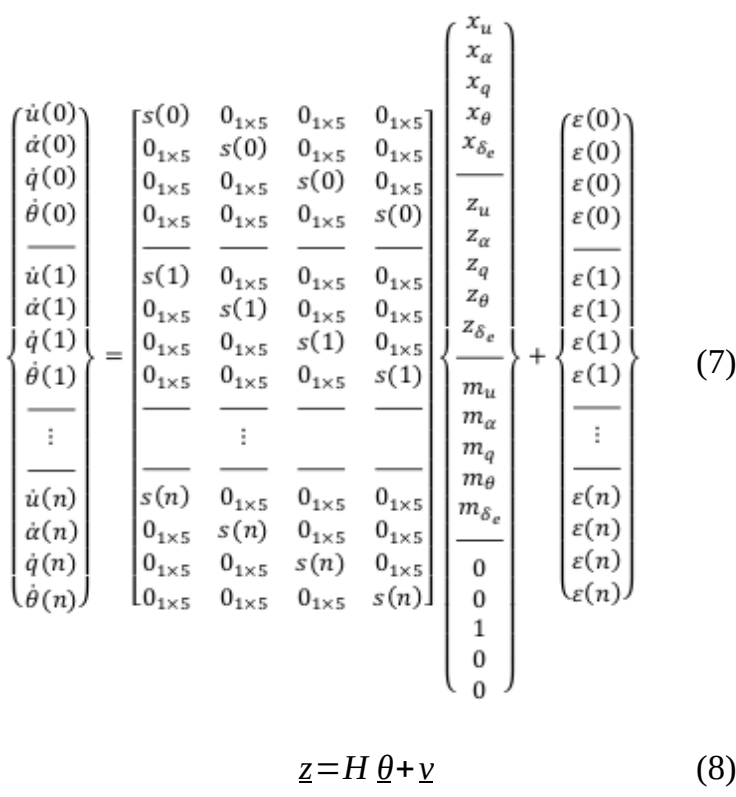

\section{Hasil dan PeMbahasan}

Defleksi elevator divariasikan dalam tiga bentuk yaitu bentuk pulse, doublet dan 3-2-1. Selain variasi input yang berbeda, waktu maksimum juga akan dibedakan, yaitu 25, 50, 100, 150 dan 200 detik. Bentuk input pulse sebesar detik ke 1 sampai ke 2 (dengan durasi 1 detik) sebesar 1 derajat (Gambar 2). Bentuk input doublet sebesar detik ke 1 sampai 2 (dengan durasi 1 detik) sebesar 1 derajat, selanjutnya dari detik 


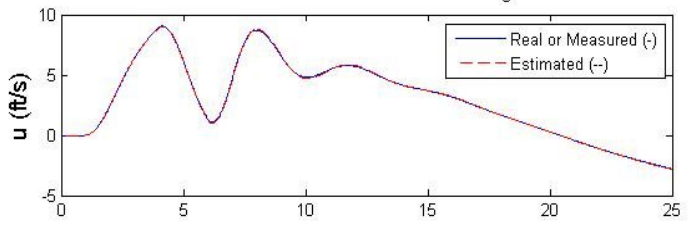

(a) Terhadap u

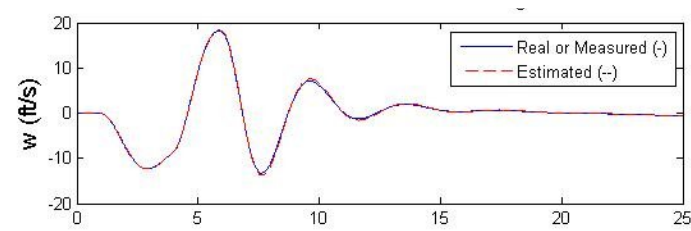

(b) Terhadap w

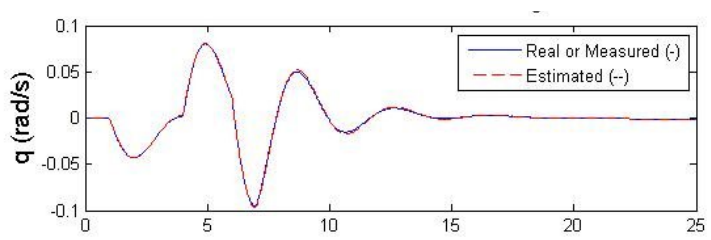

(c) Terhadap q

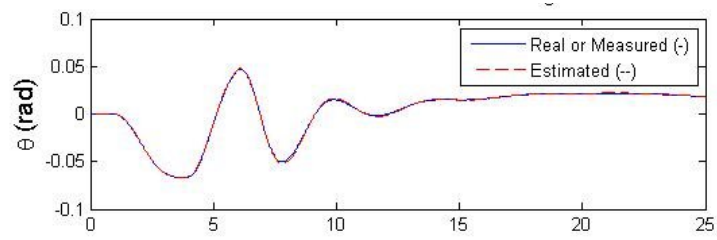

(d) Terhadap $\theta$

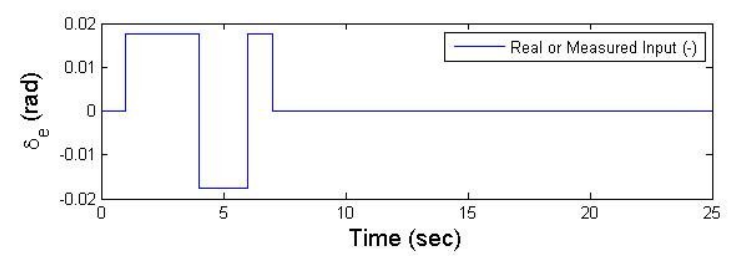

(e) Masukan 3-2-1

Gambar 5. Respons gerak longitudinal elevator riil dan estimasi

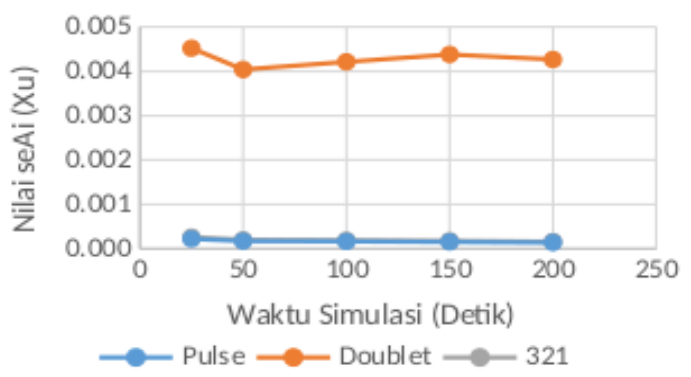

Gambar 6. Grafik Xu pada matriks seAi

2 sampai 3 (durasi 1 detik) sebesar -1 derajat, dan dari detik ke 3 sampai seterusnya adalah nol (Gambar 3). Bentuk input 3-2-1 sebesar detik ke-1 sampai 4 (dengan durasi 3 detik) sebesar 1 derajat, dan selanjutnya dari detik 4 sampai 6 (durasi 2 detik) sebesar -1 derajat, dari detik ke 6 sampai 7 sebesar 1 derajat dan dari detik ke7 sampai seterusnya adalah nol (Gambar 4).

Perhitungan IP sebagai contoh adalah pada bentuk input 3-2-1 dengan waktu maksimum 25 detik. Hasil perhitungannya disajikan dalam bentuk berikut:

$$
\begin{aligned}
A_{P I} & =\left\{\begin{array}{llll}
x_{u} & x_{w} & x_{q} & x_{\theta} \\
z_{u} & z_{w} & z_{q} & z_{\theta} \\
m_{u} & m_{w} & m_{q} & m_{\theta} \\
0 & 0 & 1 & 0
\end{array}\right] \\
& =\left[\begin{array}{llll}
0.005726 & 0.001821 & -72.915900 & -31.346700 \\
-0.088960 & -0.534440 & 310.560200 & -7.401460 \\
0.001804 & -0.007670 & -0.353260 & 0.010519 \\
0.000000 & 0.000000 & 1.000000 & -0.000000
\end{array}\right] \\
B_{\text {real }} & =\left\{\begin{array}{c}
x_{\delta_{e}} \\
z_{\delta_{e}} \\
m_{\delta_{e}} \\
0
\end{array}\right)=\left\{\begin{array}{c}
5.63000 \\
-23.80000 \\
-4.51576 \\
0.00000
\end{array}\right\}, B_{P I}=\left\{\begin{array}{c}
x_{\delta_{e}} \\
z_{\delta_{e}} \\
m_{\delta_{e}} \\
0
\end{array}\right)=\left\{\begin{array}{c}
3.8776 \\
-16.4114 \\
-4.4043 \\
-0.0000
\end{array}\right\}
\end{aligned}
$$

Selisih setiap elemen matriks hasil identifikasi terhadap matriks sesungguhnya disajikan dengan perhitungan berikut:

$$
\begin{gathered}
\left|A_{\text {real }}-A_{P I}\right|=\left[\begin{array}{cccc}
0.000626 & 0.002819 & 0.015942 & 0.006653 \\
0.003270 & 0.010556 & 1.560200 & 0.001456 \\
0 & 0 & 0.041735 & 0.009199 \\
0 & 0 & 0 & 0
\end{array}\right] \\
\left|B_{\text {real }}-B_{P I}\right|=\left\{\begin{array}{c}
1.753734 \\
7.394485 \\
0.097270 \\
0
\end{array}\right\}
\end{gathered}
$$

Dengan matrik $A$ dan $B$ hasil identifikasi parameter ini, yaitu $A_{P I}$ dan $B_{P I}$, dapat dilakukan simulasi terhadap respons input elevator yang sama. dan hasil-hasil nya disajikan berikut ini. Respons sistem terhadap masukan 3-2-1 dinyatakan dalam Gambar 5 (a)-(d).

Secara keseluruhan, dilakukan pengamatan terhadap nilai seAi yaitu nilai estimasi galat dari matriks A hasil identifikasi parameter $\left(A_{P I}\right)$. Nilai estimasi galat Xu dari masing-masing input ditunjukkan dalam Gambar 6 . Galat paling terbesar ditunjukkan oleh input doublet dan terlihat sama pada dua input lainnya yaitu input pulse dan input 3-2-1. Xu merepresentasikan kecepatan maju ke depan pada sumbu longitudinal untuk pesawat.

Nilai RMSE pada hasil identifikasi parameter matriks A dinyatakan dengan Persamaan 9. Nilai RMSE matriks A hasil identifikasi parameter ditunjukkan dalam Gambar 7. Matriks A hasil identifikasi parameter yang menggunakan input 3-2-1 memiliki galat lebih kecil daripada galat yang dihasilkan oleh input pulse dan input doublet. Ketiga bentuk inputan menunjukkan bahwa input doublet memiliki galat yang paling tinggi dan input pulse. Waktu yang diberikan hingga 200 detik menunjukkan bahwa tingkat galat makin menurun.

$$
R M S E=\sqrt{\frac{1}{m \times n} \sum_{i=0}^{n-1} \sum_{j=0}^{m-1}[f(i, j)-g(i, j)]^{2}}
$$




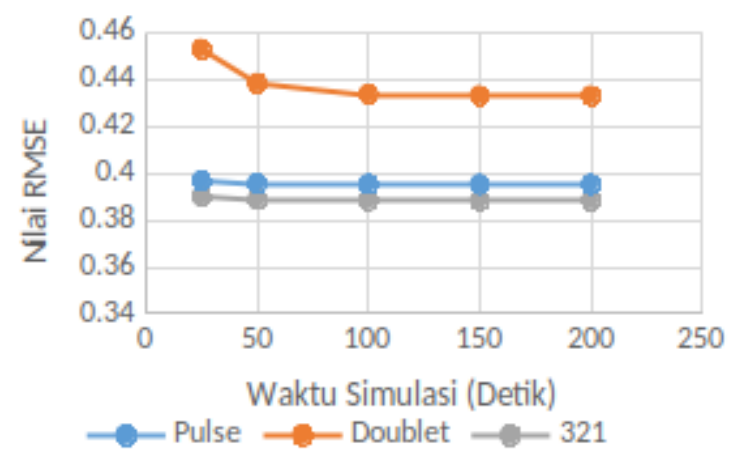

Gambar 7. RMSE matriks A hasil identifikasi parameter

Dalam penelitian ini, variasi bentuk input berupa 32-1 digunakan dalam input matra longitudinal. Bentuk ini melengkapi hasil simulasi selain step, doublet, 3-2-11 yang sudah banyak digunakan seperti dalam [5] atau pulse dalam [7]. Hasil menunjukkan bahwa bentuk input 3-2-1 dapat juga digunakan untuk matra longitudinal dan memiliki galat paling kecil di antara pulse dan doublet. Bentuk input ini dapat diterima dan dapat dimanfaatkan oleh komunikas uji penerbangan seperti halnya input 3-2-1-1 [8].

\section{KESIMPULAN}

Hasil identifikasi parameter pada pesawat Corsair A7A matra longitudinal yang menggunakan metode estimasi ordinary least square dengan bentuk inputan 32-1 memiliki nilai galat (RMSE) yang lebih kecil dibandingkan ketika menggunakan input doublet dan pulse. Semakin panjang waktu simulasi menunjukkan nilai galat yang makin menurun pada masing-masing bentuk input. Penelitian ini dapat dikembangkan untuk mengamati pengaruh input kendali terhadap hasil identifikasi parameter pada matra lateral/direksional.

\section{Daftar Pustaka}

[1] V. Klein and E. A. Morelli, Aircraft System Identification, Theory and Practice. Reston, VA: AIAA, 2006.

[2] M. B. Tischler and R. K. Temple, Aircraft and Rotorcraft System Identification, Engineering Methods with Flight-Test Examples. Reston, VA: AIAA, 2006.

[3] G. J. Mullen, Aircraft Parameter Identification using Matlab. Cranfield University, Cranfield, 2000.

[4] S. S. Wibowo, "Pengembangan Software Uji Terbang Virtual Menggunakan X-Plane, Identifikasi Parameter Menggunakan MATLAB," in Prosiding InSINas 2012, Bandung, 2012, pp. HK154-HK158.

[5] L. Saraswathi, "Estimation of Stability \& Control Derivatives from Flight Test Data of Fighter Aircraft," Defence Science Journal, vol. 50, no. 2, pp. 123-136, 2013.

[6] A. Majid, R. Sumiharto, and S. B. Wibisono, "Identifikasi Sistem Pesawat Udara Tanpa Awak Sayap Tetap Jenis Bixler," IJEIS (Indonesian Journal of Electronics and Instrumentations Systems), vol. 5, no. 1, pp. 43-54, Apr. 2015.

[7] N. K. Gupta, Input Design for Identification of Aircraft Stability and Control Derivatives. NASA, 1975.

[8] A. S. Khan, "Estimation of Stability and Control Derivatives from Flight Data of Kiran Aircraft Using Feed Forward Neural Networks," Thesis, Indian Institute of Technology Kanpur, Kanpur, India, 2000.

[9] M. V. Cook, Flight Dynamics Principles, 2nd ed. Oxford: Butterworth-Heinemann, 2007.

[10] G. L. Teper, Aircraft Stability And Control Data. NASA, Hawthorne, California, 1969. 